\title{
Description of the cyanobacterial genus Desmonostoc gen. nov. including $D$. muscorum comb. nov. as a distinct, phylogenetically coherent taxon related to the genus Nostoc
}

\author{
Pavel HrouzeK ${ }^{1,3 *}$, Alena LuKeŠOvÁ ${ }^{2}$, Jan Mareš $\check{S}^{3,4} \&$ Stefano VenturA ${ }^{5}$
}

\author{
${ }^{1}$ Institute of Microbiology, Academy of Sciences of the Czech Republic, Department of Autotrophic Microorganisms - Algatech, \\ Opatovický mlýn, 37981 Třeboň, Czech Republic; Tel.: +420384340470, e-mail: hrouzekp@gmail.com \\ ${ }^{2}$ Institute of Soil Biology, Biology Centre ASCR, v.v.i., Na Sádkách 7, 37005 České Budějovice, Czech Republic \\ ${ }^{3}$ University of South Bohemia, Faculty of Sciences, Branišovská 31, 37005 České Budějovice \\ ${ }^{4}$ Institute of Botany, Academy of Sciences of the Czech Republic, Dukelská 135, 37982 Třebon̆, Czech Republic \\ ${ }^{5}$ National Research Council of Italy, Institute of Ecosystem Study, Firenze Unit, via Madonna del Piano 10, I-500 19 Sesto \\ Fiorentino, Italy
}

\begin{abstract}
On the basis of data presented here and in earlier studies, Desmonostoc gen. nov. is described. The new genus includes the traditional species Nostoc muscorum AgardH ex Bornet et Flahault 1888, and several other strains previously assigned to the genus Nostoc, which present similar morphology and phylogenetic placement within the Desmonostoc lineage. The Desmonostoc clade is phylogenetically coherent according to 16S rRNA gene sequence analysis performed with four distinct approaches. In all phylogenetic trees, Desmonostoc formed a supported group separated from strains belonging to the related taxa Nostoc, Trichormus, and Mojavia. We also suggest that other clusters hosting strains which for their morphology resemble Nostoc, but are more distant from Nostoc commune cluster than Desmonostoc, should be reclassified into new genera in the future. Strains belonging to Desmonostoc form long vegetative filaments embedded in diffluent mucilaginous envelopes, except for primordial stages they never form a firm periderm, and the filaments are never densely coiled with compact trichomes as found in Nostoc. Both terminal and intercalary heterocytes occur, and mostly elliptical akinetes were differentiated apoheterocytically in long chains. Desmonostoc strains can be usually found in moist or wet meadow, field and forest soils, more rarely in periphyton, but to our knowledge, they are missing or very rare in desert areas. Some of these strains have been found to grow in association with mosses or as symbionts of cycadean plants and of Gunnera sp.
\end{abstract}

Key words: Cyanobacteria, Desmonostoc, ecology, Nostoc, taxonomy

\section{INTRODUCTION}

The genus Nostoc is one of the earliest described cyanobacterial genera (BORNET \& Flahault 1888). It is also the type genus for the whole order Nostocales, presenting the typical morphological characters for the order: isopolar filaments which differentiate akinetes and heterocytes (KomÁreK \& ANAGNostidis 1989). Its morphological description is based on the formation of uniseriate isopolar filaments. Chains of akinetes differentiate following an apoheterocytic scheme, while heterocytes develop in both terminal and intercalar positions. The filaments are non-branched and always embedded in mucilage. The production of mucilaginous colonies is one of two key diagnostic characters of the genus. However, the morphology of the envelopes and the level of slime production strongly vary among Nostoc strains, ranging from diffluent matter ( $N$. linckia, $N$. ellipsosporum), to firm envelopes around separate filaments ( $N$. edaphicum, $N$. punctiforme), to a thick peridermal envelope present in many benthic Nostoc species (e.g. N. pruniforme, $N$. zedterstedtii).

The other primary diagnostic character of the genus is its complex life cycle (Lazaroff \& Vishniac 1961; Lazaroff 1966; Mollenhauer 1970). In principle, the formation of the vegetative filaments can be achieved via two different cycles. In the hormogenic cycle, differentiation of hormogonia starts with the fragmentation of old vegetative filaments in positions adjacent to heterocytes; later on, new vegetative filaments will develop from hormogonia. In the sporogenic cycle, akinetes germinate into vegetative filaments (LAZAROFF 1966). These changes are accompanied by changes in the entire colony morphology and can extend over very different time ranges or even parts of the cycle can be absent in particular strains (HrouzeK et al. 2003, 2005; Mateo et al. 2012). Thus the genus Nostoc is heterogeneous when its life cycle is considered.

On the basis of results obtained using a molecular approach, the genus Nostoc was again 
found to be genetically heterogeneous. Studies taking into account large strain selections revealed its likely polyphyletic origin (ARIMA et al. 2012; TAMAs et al. 2000; HrouZeK et al. 2005; ŘEHÁKovÁ et al. 2007; Papaefthimiou et al. 2008). However, in those analyses, a large and well supported cluster containing strains of the type species of the genus, Nostoc commune Vaucher ex Bornet et Flahault, the widely used strain Nostoc punctiforme PCC 73102, and several other well-defined Nostoc species with firm sheath material ( $N$. desertorum, $N$. lichenoides, $N$. indistinguendum, $N$. edaphicum) was repeatedly found. This clade had the unifying feature of origin in soils, with many isolates well characterized by the production of massive laminar mucilaginous colonies (the diagnostic feature of the generitype) (ŘEHÁKOvÁ et al. 2007). This observation led some authors to indicate this group as "Nostoc sensu stricto" or "main Nostoc cluster" (HrouzeK et al. 2005; ŘEHÁKovÁ et al. 2007; PAPAEFTHIMIOU et al. 2008; LuKEŠOVÁ et al. 2009). At least five other groups of cyanobacterial strains exhibiting Nostoc morphology, but falling outside the main cluster were preliminarily identified (HROUZEK et al. 2005). However, relationships between them and other related genera of heterocytous cyanobacteria are not clear. The novel genus Mojavia, has been described as one of these clusters with similar morphology but lying out of the Nostoc commune cluster (ŘEHÁKOVÁ et al. 2008), but its phylogenetic position with respect to the Nostoc commune group, to Trichormus, and to a clade called by authors Nostoc group II including "Nostoc muscorum II", was unstable.

We previously reported a well-supported group of Nostoc muscorum strains located outside Nostoc sensu stricto (HrouzeK et al. 2005; PAPAefthimiou et al. 2008), that would require description as a new genus if the genus Nostoc is to be rendered monophyletic. Nostoc muscorum AGARDH is one of the classical Nostoc species circumscribed in the seminal work of Bornet et Flahault (1888) on the basis of its colony morphology and ecology. It was found to be an important member of soil communities (RoGERs et al. 1994; DE CAIRE et al. 1997) as well as a physiological model for stress tolerance and heavy metal uptake (BeKasova et al. 1999; EL-SheeKH et al. 2005); and some of its strains have been found to produce nonribosomal peptides and cytotoxic substances (TOMEK et al. 2010; HrouzeK et al. 2011). However, as often happens with the designation of cyanobacterial taxa, the species name Nostoc muscorum was not always properly used. This study brings up the evidence that strains correctly assigned to Nostoc muscorum and other strains closely related to them should be placed into a separate genus, which we designate here as Desmonostoc. A taxonomic description for the genus Desmonostoc is therefore given.

\section{Materials ANd Methods}

DNA extraction, PCR, sequence analysis. The 16SrRNA ge-ne of eight Desmonostoc strains was sequenced for this study, with an additional 13 strains sequenced by us or others prior to this study (Table 1). The same gene of one cyanobacterial strain belonging to the Nostoc commune clade was also sequenced. For DNA sequence analysis, cyanobacterial strains were cultivated in nitrogen-free BG11 medium (RIPPKA et al. 1979), and their DNA extracted with PowerPlant ${ }^{\mathrm{TM}}$ DNA Isolation Kit (MoBio Laboratories Inc.) as detailed in Cuzman et al. 2010. A DNA fragment including the $16 \mathrm{~S}$ rRNA gene plus the adjacent ITS was amplified in vitro with universal primer $16 \mathrm{~S} 27 \mathrm{~F}$ and cyanobacterial specific primer 23S30R, purified and sequenced as previously described (CuZMAN et al. 2010). A 16S rRNA gene data set, including the obtained sequences, a large selection of sequences belonging to the cluster object of this study, and several sequences of reference strains of Nostocaceae, was built using high quality sequences longer than 1100 base pairs. The sequences were retrieved from the public domain through SILVA, a comprehensive on-line resource for quality checked and aligned ribosomal RNA sequence data, available online at http://www.arb-silva.de (QUAST et al. 2013). The sequences were aligned using the SINA aligner available on the same website (PRUESSE et al. 2012), and the alignment was imported in ARB, a software environment for sequence data (Ludwig et al. 2004), where it was visually inspected and manually edited.

Phylogenetic relationships among the sequence dataset were calculated with ARB on a 16S rRNA gene fragment 1411 base pairs long in Desmonostoc muscorum NIVA-CYA 817, corresponding to positions 28 to 1491 of the reference Escherichia coli gene region. The sequence of Chroococcidiopsis thermalis PCC 7203 was added to the alignment as a non-heterocytous counterpart, while Gloeobacter violaceus VP3-01 was used to root the phylogenetic trees. A first Neighbor Joining (NJ) analysis on the 160 sequences of the complete data set was used to identify a couple of sequences for each cluster of Nostocaceae, only leaving more representatives in the Nostoc sensu stricto (N. commune) cluster. In the reduced data set, composed by 56 sequences, Neighbor joining (NJ), Maximum Likelihood (ML), and Maximum Parsimony (MP) analyses were run using ARB. NJ, ML, and MP trees have been bootstrapped 1000,500 , or 100 times respectively. For the Bayesian analysis, two runs of four Markov chains were executed using MrBayes v. 3.1.2 (Ronquist \& HuelsenBeCK 2003) for 3000000 generations with default parameters, sampling every 100 generations (the final average standard deviation of split frequencies was lower than 0.01). First $25 \%$ of sampled trees were discarded as burnin, the rest was used to calculate posterior probabilities of branches.

16S rRNA gene similarities between the $\mathrm{N}$ and $\mathrm{D}$ clusters and between D1 and D2 subclusters (Fig. 1) were calculated with ARB on a gene fragment 1410 base pairs long, corresponding to positions 28 to 1490 of the reference Escherichia coli gene region.

Morphological observations. Many of the strains have had their morphology documented in the past (Table 2). In this study, five additional cultured strains were characterized (Table 2). All observations were performed on cultures growing on agar plates. The morphology of the isolates was studied in young, exponentially growing and old cultures of 
Table 1. Origin of the strains belonging to Desmonostoc sp. cluster. Strains characterized in this study are in bold. The strains characterized in other studies are marked as: (1) Hrouzek et al. 2003, (2) PApaefthimiou et al. 2008, (3) Mateo et al. 2011.

\begin{tabular}{|c|c|c|}
\hline Strain & Habitat/Locality of isolation & Accession number \\
\hline $\begin{array}{l}\text { D. muscorum } \\
\text { NIVA-CYA } 817^{(1)}\end{array}$ & soil, abandoned field /Dlouhá ves - Czech Republic & AJ630451 \\
\hline D. muscorum $\mathrm{II}^{(1)}$ & soil, meadow /Jevany - Czech Republic & AJ630452 \\
\hline $\begin{array}{l}\text { D. muscorum } \\
\text { NIVA-CYA } 818^{(2)}\end{array}$ & soil, wet meadow /Dlouhá ves - Czech Republic & AM711523 \\
\hline D. muscorum $2 / 91^{(2)}$ & soil, arable field / Nezamyslice - Czech Republic & AM711524 \\
\hline D. muscorum $\mathrm{De}^{(2)}$ & Symbiont of Dioon edule/botanical garden in Rome - Italy & AM711534 \\
\hline Desmonostoc sp. OSNI32s01 & Periphyton, Sítinný pond / Poodřrí - Czech Republic & HG004587 \\
\hline Nostoc sp. PCC8306 & waterlogged soil/ West Africa & HG004584 \\
\hline Desmonostoc sp. TO1SO1 ${ }^{(\#)}$ & soil, abandoned field /Tuscany - Italy & AM711549 \\
\hline Desmonostoc sp. Cc2 $2^{(2)}$ & symbiont of Cycas circinalis /botanical garden in Pisa - Italy & AM711532 \\
\hline Desmonostoc sp. Cr3 & $\begin{array}{l}\text { symbiont of Cycas revoluta /botanical garden in Bologna } \\
\text { - Italy }\end{array}$ & HG004581 \\
\hline Desmonostoc sp. Cr4(2) & $\begin{array}{l}\text { symbiont of Cycas revoluta/botanical garden in Florence - } \\
\text { Italy }\end{array}$ & AM711533 \\
\hline Desmonostoc sp. Ds & $\begin{array}{l}\text { symbiont of Dioon spinulosum /botanical garden in Rome } \\
\text { - Italy }\end{array}$ & HG004579 \\
\hline Desmonostoc sp. $8964^{(2)}$ & symbionf of Gunnera prorepens / New Zealand & AM711541 \\
\hline Desmonostoc sp. MA4- & Biofilm of Matarrana stream/Teruel, Spain & HM623782 \\
\hline $\begin{array}{l}\text { UAM307(3) } \\
\text { Desmonostoc sp. РCC9230 }\end{array}$ & Cycas sp. symbiont & HG004585 \\
\hline Desmonostoc sp. PCC8107 & na & HG004579 \\
\hline Desmonostoc sp. PCC7422 & $\begin{array}{l}\text { symbiont of Cycas sp./botanical garden in Stockholm - } \\
\text { Sweden }\end{array}$ & HG004586 \\
\hline Desmonostoc sp. PCC6302 & na & HG004582 \\
\hline $\begin{array}{l}\text { Desmonostoc entophytum IAM } \\
\text { M-267 }\end{array}$ & na & AB093490 \\
\hline Desmonostoc linckia IAM & na & AB074503 \\
\hline $\begin{array}{l}\text { M-251 } \\
\text { Desmonostoc sp. } 8938^{(\#)}\end{array}$ & symbiont of Gunnera dentata/New Zealand & AY742454 \\
\hline
\end{tabular}

3, 10 and 30 days respectively. Cyanobacteria were examined under an Olympus CX40 light microscope equipped with a digital camera. The morphology of colonies, vegetative filaments, hormogonia, mucilaginous sheaths of filaments, and the different cell types (vegetative cells, heterocytes, and akinetes) were studied. Cell parameters were measured using the DP-SOFT software; 50 to 300 measurements were taken for each parameter to describe the trait variability. The morphology of the mucilaginous sheaths was classified into two main categories: diffluent (where no sharp edges of micro-colony could be observed), and enveloping filament (delicate, not lamellated sheath expanding 2-20 $\mu \mathrm{m}$ around the filament). The collected data were analyzed with the software Statistica for Windows v. 9 (StatSoft).

Ecology observations. Information about the ecology of the Desmonostoc muscorum group presented in this report were based on the analysis of algal and cyanobacterial communities from about 500 soil samples collected since 1985. Investigated soils originated from different localities in many countries of Europe, the USA, Canada, Mexico, Cuba, Brazil, Africa (Egypt, Kenya), Indonesia, Siberia, Svalbard, 
Arctic, Antarctica. They included soils from cultivated fields and meadows, from grasslands, steppe, prairie, different shrub communities, forests, post-mining reclaimed and unreclaimed sites, post-fire, post-volcanic sites, deglaciated areas, cave sediments, hot desert soils, frost heaved soils, peat soils, garden soils, saline soils, polar soils, guts of soil invertebrates collected in the field, and moss epiphytes. Both direct light and epifluorescence microscopy and cultivation methods (dilution plate method on BBM, BG11) were used for the identification and life cycle studies from the natural samples.

\section{Results AND Discussion}

After preliminary or partial data were previously published (Hrouzek et al. 2005; Papaefthimiou et al. 2008; Ř́hÁKovÁ et al. 2008; Mateo et al. 2011), the existence of a unique, phylogenetically coherent clade for Desmonostoc muscorum and allied strains has been confirmed here by the addition of numerous other strains. We performed a comprehensive phylogenetic analysis including strains and species of Nostoc, Trichormus, and Mojavia that have been demonstrated in past studies to be closely related to the Desmonostoc cluster (HrouzeK et al. 2005; PAPAefthimiou et al. 2008; ŘEHÁKOvÁ et al. 2008; MATEO et al. 2011); we also added a few other genera representing more distantly related Nostocaceae. Moreover, we characterized four new strains (Nostoc sp. OSNI32s01, PCC 8306, Cr3 and Ds), demonstrating that they belong to the genus Desmonostoc (Figs 1, 2; Table 1). As shown by a phylogenetic analysis performed with four different methods (Figs 1,2), the 22 strains of Desmonostoc were always joined in a single, monophyletic cluster, distinct but related to the Nostoc commune cluster, exactly as it was previously shown with smaller taxon sampling (HrouzeK et al. 2005; PAPAefthimiou et al. 2008; ŘEHÁKOvÁ et al. 2008). Desmonostoc was supported as a monophyletic taxon in analyses performed by $\mathrm{NJ}$, MP, ML approaches with bootstraps values of 95, 98 and $77 \%$, respectively (Fig. 1), and also in a Bayesian analysis where it obtained 100\% support (Fig. 2). According to the Bayesian analysis, Desmonostoc formed a sister group to the Nostoc commune cluster (supported 98\%), with Mojavia as the nearest relative of this larger cluster (Fig. 2). The placement of these three genus-clusters in the phylogenetic tree was unstable in NJ, MP, and ML analyses and never supported by high bootstrap values. Also for the other genus-clusters included with few representatives as references in the phylogenetic analysis, their existence as monophyletic clusters was fully supported, but their distribution along the tree was not stable. On the other hand, at the deepest level the entire heterocytous clade was fully supported in all analyses. This was not unexpected since, in this phylogenetic study, clusters of Nostocaceae were underrepresented by a single or very few strains each, while $N$. commune and Desmonostoc were included in the analysis with 11 and 22 sequences respectively, and phylogenetic inference methods are sensitive to unbalanced taxonomic sampling, and even more sensitive to the presence of orphans. The separation of Desmonostoc from the Nostoc commune cluster is also supported by the position of strains "Nostoc muscorum" I and II in a phylogenetic analysis using rpoB sequences (RAJANIEMI et al. 2005). On the basis of this evidence, we also recommend that all other groups of cyanobacteria morphologically resembling the genus Nostoc, but lying more distant from Nostoc sensu stricto than Desmonostoc and showing some morphological support, should be described as new genera in the future.

The sequence similarity between strains within the Desmonostoc cluster (subsequently referred to as cluster D, as in Fig. 1) and strains within Nostoc commune cluster (subsequently referred to as cluster N) ranged between 94 and 97\%. Among the 22 Desmonostoc sequences (Fig. 1) in cluster D, two stable and well defined subclusters could be easily recognized. Subcluster D1 hosted 14 Desmonostoc sequences of various habitat and geographical origins, sharing sequence similarities higher than 99\% (Figs 1, 2; Table 1). Six cycad symbionts (Cc2, Cr3, Ds, Cr4, PCC7422 and PCC 9230), two symbionts of Gunnera sp. (8964:3 and 9231), three free-living strains (OSNI32s01, TO1SO1 and PCC8306), and three strains of unknown origin were placed within this subcluster. Strain OSNI32s01, characterized in this study, had been isolated from the periphyton of Sitinný pond (Poodří, Czech Republic). The other two strains, TO1SO1 and PCC 8306, were isolated from wet soils in Tuscany and West Africa, respectively. In addition, one Pasteur culture collection strain (PCC 8107) of unknown origin clustered here. Since the morphology and origin of "Nostoc entophytum" and "Nostoc linckia" are unknown, we cannot at this time confirm the identity of these species. If these strains were correctly identified, a putative species $D$. entophytum would include at least five of the presently characterized strains.

Subcluster D2, consisting of eight strains with sequence similarities higher than $99 \%$, was supported by the NJ, NP and ML methods (96, 99 and 59\% for NJ, MP and ML, respectively) and by $100 \%$ by Bayesian analysis; subcluster D2 could be further subdivided into two small subgroups with full support by all phylogenetic methods used. One of them is an extremely tight group made up by four free-living strains isolated from meadow soils (Desmonostoc muscorum NIVA-CYA 817, NIVA-CYA 818, II and Lukešová 1/87) and by the symbiont $D$. muscorum De (Fig. 1). Because of the nearly complete $16 \mathrm{~S}$ rRNA gene identity of these five strains and of their high morphological resemblance (see below), we suggest that they should be assigned to the single species Desmonostoc muscorum. We also suggest $D$. muscorum to be the type species of the genus with Desmonostoc muscorum NIVA-CYA 818 


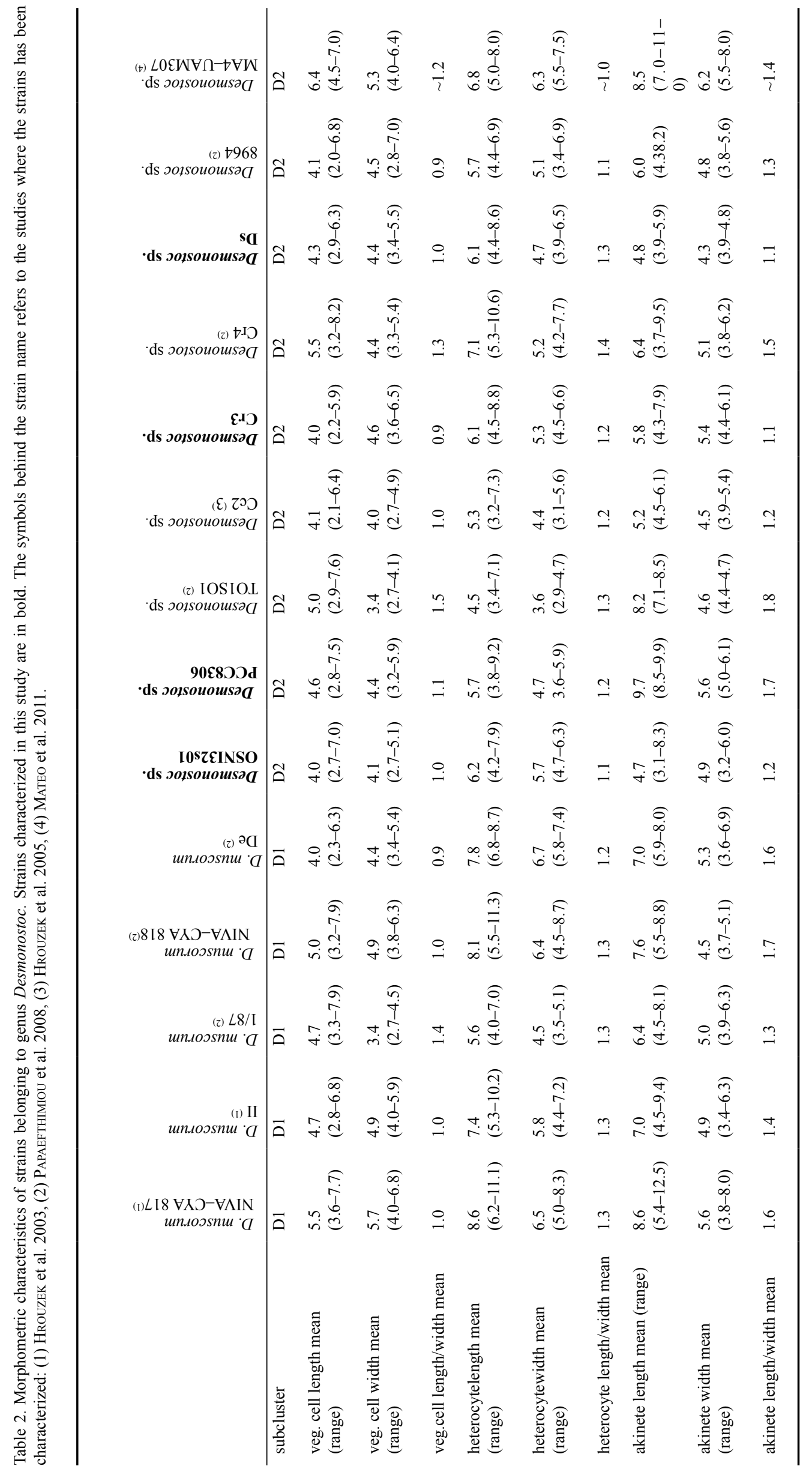




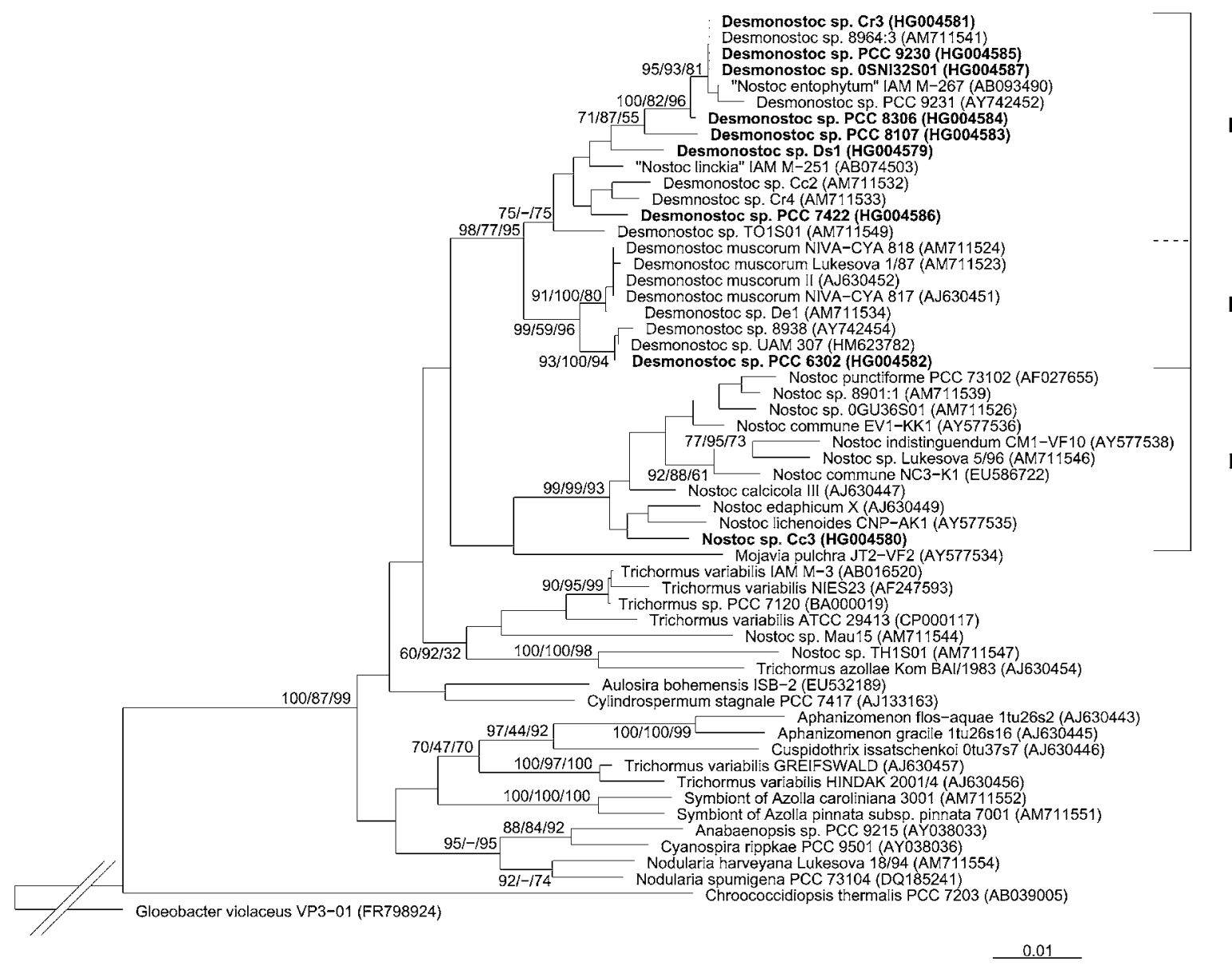

Fig 1. Phylogenetic analysis (NJ tree) based on 16S rRNA gene sequences. Clades of Nostoc sensu stricto (marked as N) and Desmonostoc cluster (marked as D) can be recognized, as well as the separation of two Desmonostoc subclusters (D1 and D2). The numbers above the nodes refer to $\mathrm{NJ} / \mathrm{ML} / \mathrm{MP}$ bootstrap values.

as the reference strain for morphological comparison or the type strain in the future.

A compact and stable group of three sequences (Nostoc sp. 8938, UAM307-MA4 and PCC 6302) belonging to strains characterized in other works, is also placed in the D2 subcluster. Strain UAM307MA4 was isolated from a biofilm in the calcareous Marranta stream in Spain (MATEO et al. 2011), while Desmonostoc sp. 8938 is a symbiont of Gunnera sp. (SvenING et al. 2005). With the presently available data, it is not clear if this latter subgroup of three strains should be assigned to the same species $D$. muscorum as the other five strains of subcluster D2, or described as a separate taxon.

Morphological characterization did not produce clear separation of taxa nor did it strongly support the phylogenetic differences between the D1 and D2 clades (Table 2). The mean cell/filament width ranged between 3.4 and $5.7 \mu \mathrm{m}$. For this character, there is no significant statistical difference between Desmonostoc and Nostoc strains as tested using ttests. Cells were isodiametric to barrel-shaped. Also the shape and dimensions of intercalary heterocytes between these two groups did not differ significantly.
Previously, we noticed that in the strains of $D$. muscorum, hemispherical terminal heterocytes were lacking, and when terminal heterocytes were present they were oval-shaped and similar to intercalary heterocytes (HROUZEK et al. 2005). However, recently, Mateo and co-authors (MATEO et al. 2011), studying the life cycle of Desmonostoc MA4-UAM307 which clustered within the D1 subcluster (Fig.1), reported the occurrence of conical terminal cells on hormogonia from which terminal heterocytes differentiated. Also, we found that strain OSNI32s01 differentiated conical terminal heterocytes at the end of its hormogonia when they were developing into vegetative filaments (Fig. 3j). Since both these strains clustered in the D cluster with good support, the shape of the terminal heterocytes seemed to be variable within this group. We conclude that there are likely multiple species of Desmonostoc within our sampled strains, but we lack sufficient morphological and genetic evidence to name these taxa at present. Consequently, we only identify one species, D. muscorum, in the present work. Future characterization and study will likely lead workers to identify and characterize more species inside the genus Desmonostoc. 


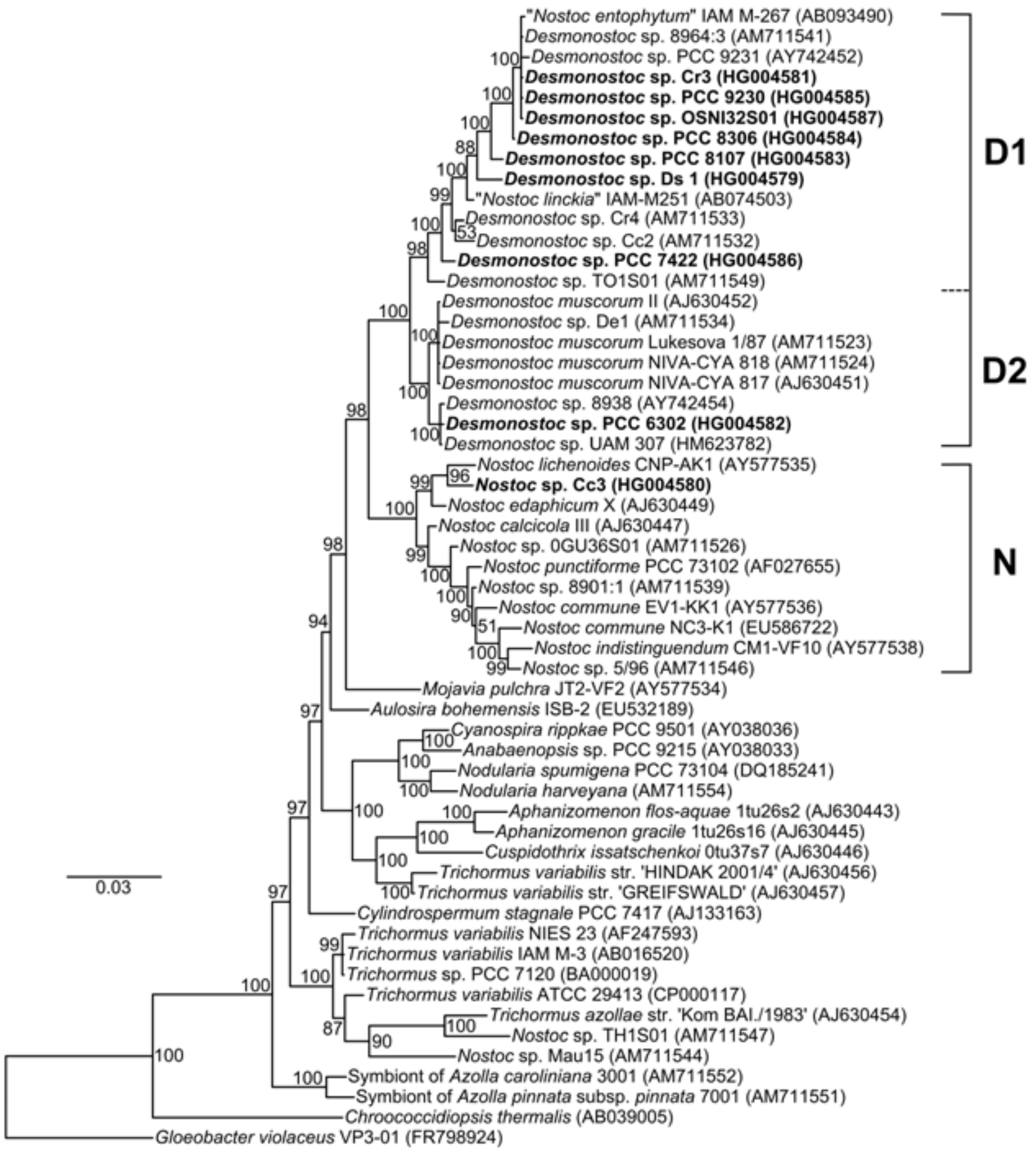

Fig 2. Bayesian inference tree inferred from 16S rRNA sequences. Posterior branch probabilities are given at the nodes. Nostoc commune cluster (N) and Desmonostoc (D) form sister clades in this tree, with Mojavia pulchra branching outside both clusters (cf. Fig. 1.). Desmonostoc further divides into two well supported subclusters (D1 and D2).

Despite the morphological similarities between D and $\mathrm{N}$ clusters, we found several remarkable differences between these two groups. The morphology of akinetes and vegetative filaments as well as the life cycle were consistent within Desmonostoc but different from Nostoc sensu stricto. The first similar feature among the strains of the D cluster is the type of life cycle and similar formation of mucilaginous matter. Most of the life cycle the strains are living in long vegetative filaments (Fig. 3) consisting of hundreds of cells
(Hrouzek et al. 2005; Mateo et al. 2011). Densely coiled filaments with akinete-like cells (HrouzeK et al. 2003) can be observed only in early stages and not throughout the cell cycle. Instead, this latter feature is frequent in most Nostoc strains. The frequent presence of very long vegetative filaments is the reason for the proposed name Desmonostoc (from Greek desmus=chain). The filaments are embedded in diffluent mucilaginous matter (e.g. strains $\mathrm{Cc} 2, \mathrm{De}, \mathrm{Cr} 4$ ) or are surrounded by diffluent envelopes as in strains D. muscorum NIVA- 

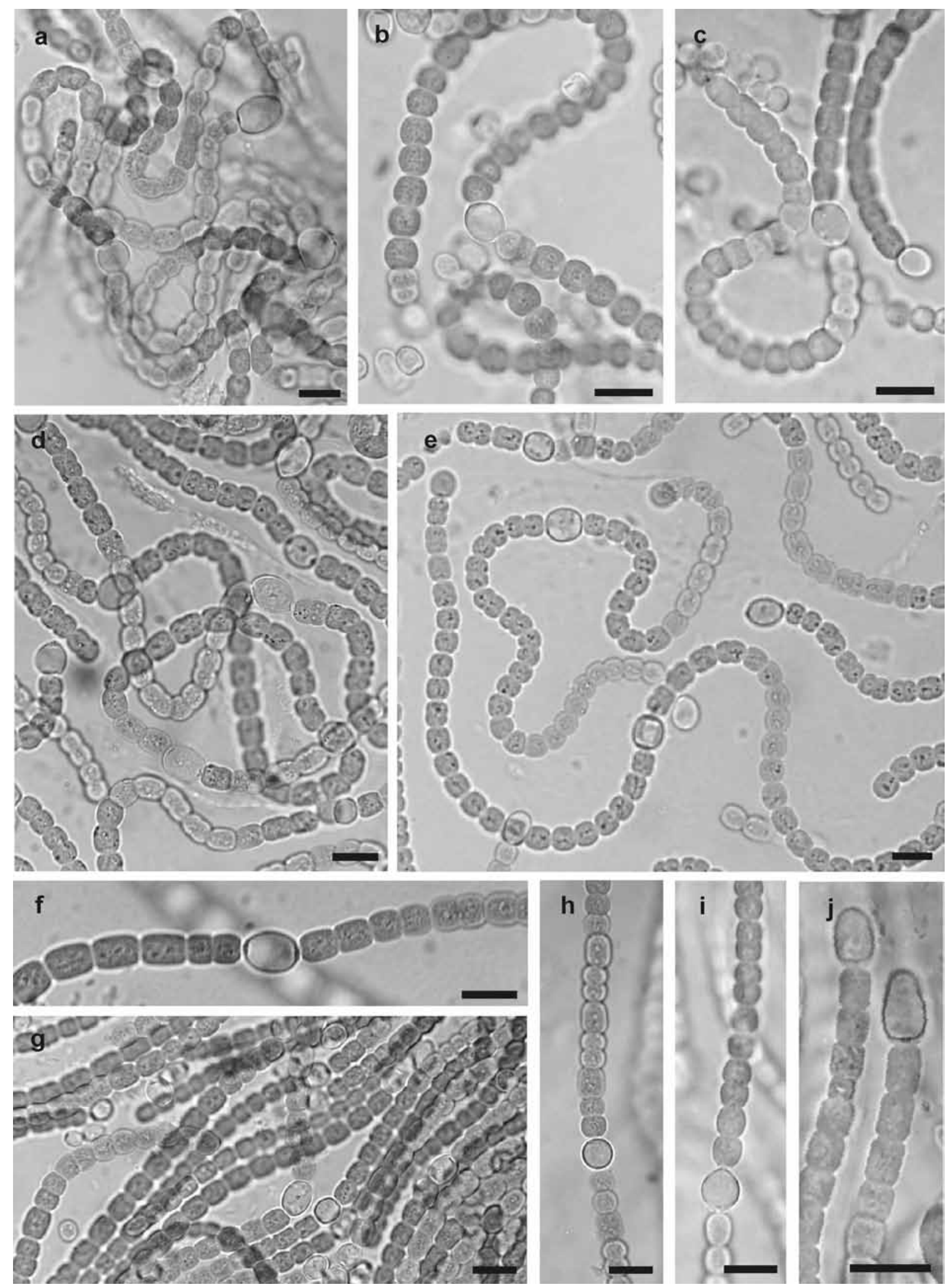

Fig 3. Vegetative filament morphology of Desmonostoc strains: (a) Desmonostoc sp. Cr4, (b) Desmonostoc sp. Cr3, (c) Desmonostoc sp. Ds, (d) Desmonostoc muscorum Desmonostoc muscorum NIVA-CYA 818, (e) Desmonostoc muscorum NIVA-CYA 817, (f) Desmonostoc muscorum NIVA-CYA 817, (g) Desmonostoc sp. Cc2, (h) Desmonostoc muscorum De, (i) Desmonostoc sp. OSNI32s01, (j) terminal heterocytes of Desmonostoc sp. OSNI32s01. 

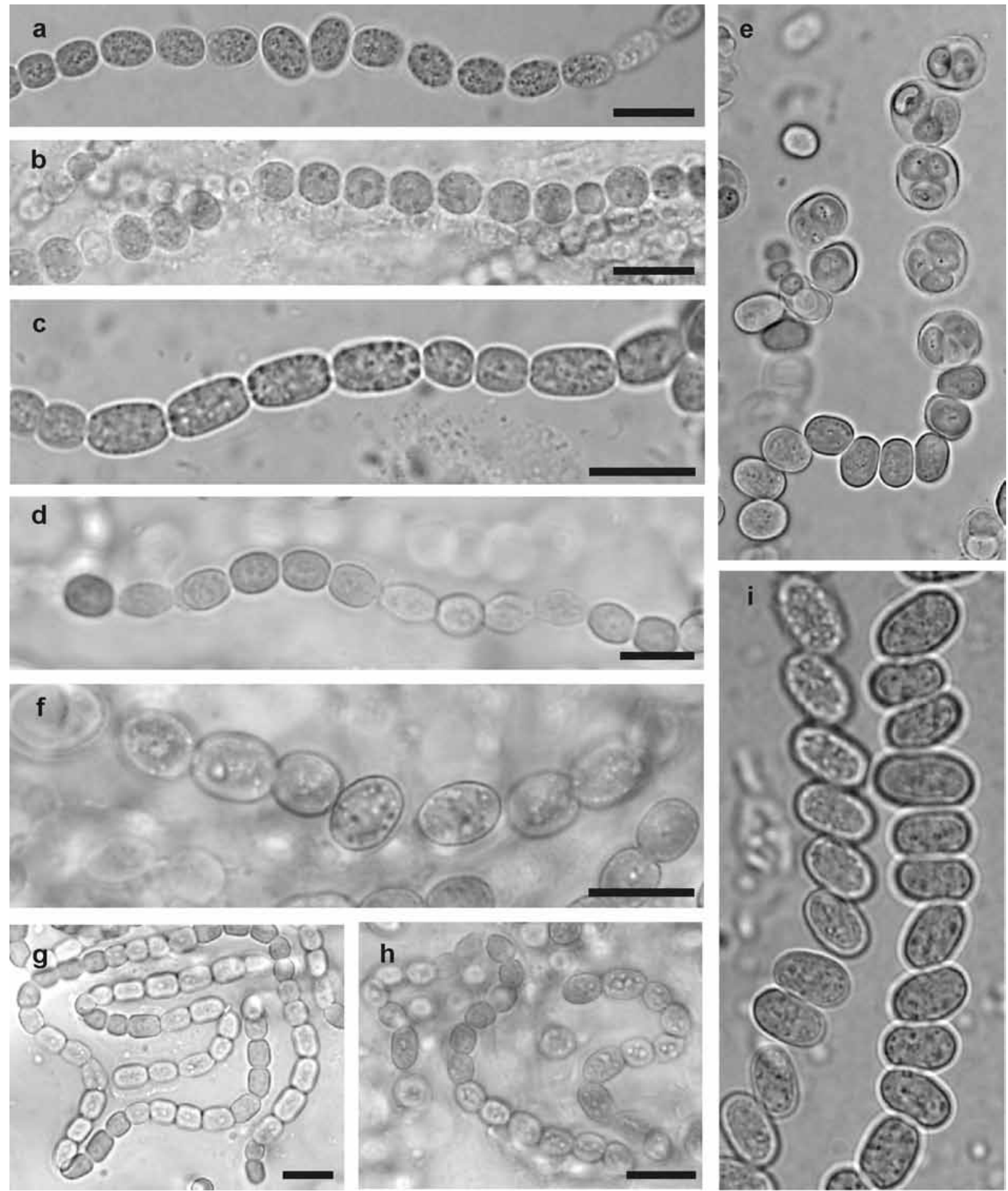

Fig 4. Akinete morphology of Desmonostoc strains: (a) Desmonostoc muscorum II, (b) Desmonostoc muscorum De, (c) Desmonostoc muscorum NIVA-CYA 818, (d) Desmonostoc sp. Cr4, (e) germinating akinetes of Desmonostoc muscorum NIVA-CYA 817, (f) Desmonostoc muscorum De, (g) Desmonostoc sp. Cr4, (h) Desmonostoc sp. Cc2, (i) Desmonostoc muscorum NIVA-CYA 817. 
Table 3. Localities with significant ocurrence of Desmonostoc muscorum with designation of soil type and pH.

\begin{tabular}{|c|c|c|c|c|}
\hline country & locality & soil type/habitat & soil type & pH \\
\hline Czech Republic & Jevany (Prague) & humid cultivated meadow & cambisol & 6.2 \\
\hline Czech Republic & České Budějovice, Zavadilka & cultivated garden soil & cambisol & 5.7 \\
\hline Czech Republic & České Budějovice, Zavadilka & earthworm gut content & garden soil & \\
\hline Czech Republic & Třeboň & wet meadow & cambisol & 5.2 \\
\hline Czech Republic & Nezamyslice & arable field & cambisol & $\sim 6.2$ \\
\hline Czech Republic & Dlouhá Ves (South Bohemia) & arable field & cambisol & 5.7 \\
\hline Czech Republic & Dlouhá Ves (South Bohemia) & abandoned field (fallow) & cambisol & 6.0 \\
\hline Czech Republic & Dlouhá Ves (South Bohemia) & wet meadow & cambisol & 5.3 \\
\hline Czech Republic & Vintířov (Sokolov) & $\begin{array}{l}9 \text { yrs old reclaimed post- brown coal } \\
\text { mining site by Alnus glutinosa seedlings }\end{array}$ & $\begin{array}{l}\text { tertiary } \\
\text { cypris clay }\end{array}$ & 7.1 \\
\hline Czech Republic & Vintířov (Sokolov) & young reclaimed post coal mining site & $\begin{array}{l}\text { tertiary } \\
\text { cypris clay }\end{array}$ & 7.4 \\
\hline Czech Republic & Pastviny (Sokolov) & $\begin{array}{l}\text { young spontaneously succeeded post } \\
\text { mining sites, partly vegetated }\end{array}$ & $\begin{array}{l}\text { tertiary } \\
\text { cypris clay }\end{array}$ & 7.5 \\
\hline Czech Republic & Dlouhá Ves (South Bohemia) & arable field & cambisol & 5.8 \\
\hline Slovakia & Domica cave & cave sediment & & 7.5 \\
\hline USA, Indiana & Somerville mine & $\begin{array}{l}\text { ca } 5 \text { yrs old reclaimed post-brown coal } \\
\text { mining site (forest area) }\end{array}$ & silt loam & 6.6 \\
\hline USA, Indiana & Indiana Burning Stars & $\begin{array}{l}\text { ca } 5 \text { yrs old reclaimed post-brown coal } \\
\text { mining site (long-leave prairie area) }\end{array}$ & silt loam & 6.7 \\
\hline USA, Tennessee & Laurel grove nr. Oak Ridge & $\begin{array}{l}\text { ca } 5 \text { yrs old reclaimed and } \\
\text { spontaneousely succeded post-brown } \\
\text { coal mining sites }\end{array}$ & loam & $\begin{array}{l}6.0- \\
6.7\end{array}$ \\
\hline USA, Illinois & $\begin{array}{l}\text { Carbondale, Sahara-Ashby } \\
\text { Kolar Research Plots }\end{array}$ & $\begin{array}{l}\text { different tree plantations on reclaimed } \\
\text { or unreclaimed post- brown coal } \\
\text { mining sites }\end{array}$ & shales & $\sim 7.0$ \\
\hline USA, Illinois & $\begin{array}{l}\text { Carbondale, Sahara-Ashby } \\
\text { Kolar Research }\end{array}$ & remains of an original prairie & loam & 6.8 \\
\hline USA, Illinois & $\begin{array}{l}\text { Carbondale, Sahara Coal } \\
\text { Company }\end{array}$ & $\begin{array}{l}\text { post coal mining sites reforested by } \\
\text { loblolly pine trees }\end{array}$ & shale & 6.9 \\
\hline Africa, Kenya & Tsavo & shoreline of a waterhole & lateritic soil & na \\
\hline Africa, Kenya & Amboseli & nearby a shallow freshwater lagoon & silt & na \\
\hline
\end{tabular}

CYA 817, NIVA-CYA 818, Lukešová 2/91 (HROUZEK et al. 2003, 2005) or loosely enveloping the filament as in MA4-UAM 307 (MATEO et al. 2011).

The hormogonial morphology is variable within this group, from long trichomes consisting of more than 50 cells (MA4 UAM 307, NIVA-CYA 817 and NIVA-CYA 818 (HrouzeK et al 2003, 2005,
Mateo et al. 2011) to short trichomes as in strain Cr4. As it can be seen in Fig. 4, the members of Desmonostoc form robust and clearly recognizable akinetes (Figs 4a,b,c,d,f,i), although we observed also some exceptions in strain $\mathrm{Cr} 4$ (Fig. 4d). Long chains of akinetes (usually more then 10) can be observed during sporulation (Figs 4a,c,i). Comparing the akinete 
dimensions of Desmonostoc with those of the members of Nostoc sensu stricto, we found that members of Desmonostoc had similar width, but the akinetes tended to be longer $(p=0.031)$. Their shape was also more elliptic (the statistic difference in length/width ratio was significant at 5\% level of significance). Although the akinetes could possess a variable shape even within the same filament, the elliptic shape prevailed. Within Desmonostoc muscorum the akinetes were elliptic, strongly granulated and sometimes perpendicular to the filament axis (Fig. 3i). The germination of akinetes inside the filament was also observed in this strain (Fig. 3d).

\section{Desmonostoc Hrouzek et Ventura gen. nov.}

Colonies in nature usually pale to dark green to brown, with diffluent mucilage within a firmer surface layer. Filaments long, aggregated into rounded macrocolonies (up to $2 \mathrm{~cm}$ in diameter) or in amorphous film, firm mucilage or formation of compact micro-colonies can be observed rarely and only in primordial state or stress conditions. Cells barrel-shaped to oval, $3.5 \mu \mathrm{m}$ wide or wider on average. Heterocytes terminal and intercalary, solitary. Akinetes frequently occurring, produced apoheterocytically in long chains (10 or more cells), variable in shape but mostly elliptical in the population, easily distinguished from vegetative cells, up to $10 \mu \mathrm{m}$ long, up to $6 \mu \mathrm{m}$ wide (average size exceeds $4.8 \mu \mathrm{m}$ long and $4.2 \mu \mathrm{m}$ wide). Reproduction both by akinetes and by motile hormogonia which are formed by fragmentation of the vegetative filaments.

Type species: Desmonostoc muscorum (Agardh ex Bornet et Flahault) Hrouzek et Ventura comb. nov.

\section{Desmonostoc muscorum (AgARdH ex Bornet et Flahault) Hrouzek et Ventura comb. nov. Basionym: Nostoc muscorum AgardH (1812, Dispositio Algarum Sueciae, p. 44) ex Bornet et Flahault (1888, Revision des Nostocacées Hétérocystées, Ann. Sc. Nat. $7^{\text {th }}$ Ser: 7:200). \\ Holotype specimen: AgaRdH Herbarium 6154 (LD), collected July 1810, from mosses in Jaders Bruk, Scania, Sweden. \\ Reference strain: NIVA-CYA 818}

Young colonies \pm hemispherical, later forming mucilaginous, amorphous mats, up to several $\mathrm{cm}$ in diameter, blue-green, later yellow-brown to olive-green, with densely entangled filaments. Long vegetative filaments irregularly flexuous and except for the earliest stages never forming compact microcolonies. Sheaths distinct at the margin of colonies, colourless to yellow-brown. Inside the colony only diffluent mucilage loosely enveloping filaments. Cells shortly barrel-shaped to cylindrical, shorter than wide up to isodiametric, rarely a little longer than wide, 3-5(6.5) $\mu \mathrm{m}$ long, (3.2)4.5-6.8 $\mu \mathrm{m}$ wide. Heterocytes almost spherical or barrel-shaped, (4)6-7.9 $\mu \mathrm{m}$ long, (4)4.5-6.3(7) $\mu \mathrm{m}$ wide. Akinetes occurring in long chains, oval, with smooth, colourless to yellow cell wall, (6.3)8-12 $\mu \mathrm{m}$ long, $4-8 \mu \mathrm{m}$ wide.

Ecology of Desmonostoc muscorum: Strains corresponding morphologically to D. muscorum included in this study were found in less than $10 \%$ (ca $8 \%$ ) samples studied by us. No occurrence of $D$. muscorum has been observed in soils below $\mathrm{pH}=5.0$. However, slightly acid to neutral soil $\mathrm{pH} 5.3-7.1$ seemed to be more favourable than alkaline soil (Table 3). From studied localities, D. muscorum was isolated most frequently in various meadow soils and arable or abandoned fields (cultivated soils) (e.g. LuKEŠOvÁ 1993), and in young successional partly vegetated sites in post-coal mining sites both reclaimed by different tree species and spontaneously recovered in the Czech Republic (e.g. LuKeŠovÁ 2001) and in the USA (Indiana, Illinois, Tennessee). We isolated D. muscorum also from fecal pellets of the millipede Glomeris hexasticha collected from an abandoned field (LuKEŠOVÁ \& TAJOVSKÝ 1999) or gut contents of earthworms from garden soil and found it also growing epiphytically on mosses. We have never observed mass development of D. muscorum on the soil surface, and have only rarely found this species as a dominant or subdominant taxon in soil samples.

The species has never been found in completely barren soils, exposed to extreme abiotic conditions, such as in polar or hot sandy deserts, post-mining or saline or other locally arid sites. In soils with $\mathrm{pH}$ not limiting cyanobacterial growth, water availability seemed to be the factor determining the distribution of D. muscorum, thus local microclimate conditions seem to be very important. According to the literature, $D$. muscorum inhabits a much broader spectrum of biotopes than we recorded in our study. In addition to meadows and cultivated soils, its occurrence was reported also from forests (Aleksachina \& Shtina 1984), paddy fields (de HALPERIN et al. 1992), wet moss carpets in Antarctica (BROADY 1978), cryptogamic soil crusts in subpolar areas (SKujA 1964), peat bogs (BusyginA 1976) aerophytic in caves and on rocks (Uzunov et al. 2008), as phycobiont (O'Brien et al. 2006), and even in cryptogamic soil crusts and soils in desert rangelands in biotopes with favourable microclimatic conditions (JoHANSEN et al. 1984; NoviČKOVA-IvANOVA 1980). Although it is mentioned also from freshwater habitats (ABOAL 1996; LEGHARI et al. 2005), mainly from periphyton, most reports were published from terrestrial environments.

ACKNOWLEDGEMENTS

The competent technical support of Cristina Mascalchi for the molecular work is gratefully acknowledged. Dr. Petr Hašler is acknowledged for providing the strain OSNI32s01. The work was supported by the Center for Algal Biotechnology Třeboň ALGATECH (CZ. 1.05/21.00/03.0110) and by a long-term research development project no. RVO 67985939. Original data on PCC strains described in this work were partly obtained with the support of 
the EC project "Biodiversity: Applied and Systematic Investigations of Cyanobacteria” (BASIC), contract BIO4-CT96-0256.

\section{REFERENCES}

AвоAL, M. (1996): Epipelic algal communities in irrigation chanels of Southeastern Spain. - Algological Studies 82: $117-131$.

Agardh, C.A. (1812): Dispositio Algarum Sueciae: 1-45, Litteris Berlingianis, Lund.

aLEKSAChina, T.I. \& ShtinA, E.A. (1984): Soil algae of forest biogenoses. Pochvennyje vododrosli lesnych biogeocenozov 1. - 149 pp., Nauka, Moskva.

Anagnostidis, K. \& KomÁreK, J. (1988): Modern approach to the classification system of cyanophytes 4 Nostocales. - Algological Studies 56: 517-526.

Arima, H.; Horiguchi, N.; Takaichi, S.; Kofuji, R.; Ishida, K.; Wada, K. \& SAKamoto, T. (2012): Molecular genetic and chemotaxonomic characterization of the terrestrial cyanobacterium Nostoc commune and its neighboring species. - FEMS Microbiol. Ecol. 79: 34-45.

Bekasova, O.D.; OrleanskiI, V.K. \& Nikandrov, V.V. (1999): Accumulation of cadmium, titanium, and aluminum by the cyanobacterium Nostoc muscorum. - Microbiology 68: 751-758.

Bornet, E. \& Flahault, C. (1888): Revision des Nostocacées hétérocystées contenues dans les principaux herbiers de France. - Annales des Sciences Naturelles, Botanique 7: 177-262.

BRoAdy, P.A. (1978): The growth of Nostoc muscorum in a moss community in Antarctica. - Brit. Phycol. J. 13: 197-207.

deCaire, G.Z. ; deCano, M.S. ; deMule, M.C.Z. ; Palma, R.M. \& Colombo, K. (1997): Exopolysaccharide of Nostoc muscorum (cyanobacteria) in the aggregation of soil particles. - J. Appl. Phycol. 9: 249-253.

Cuzman, O.A. ; Ventura, S. ; Sili, C. ; Mascalchi, C. ; Turchetti, T. ; D'Acqui, L.P. \& Tiano, P. (2010): Biodiversity of phototrophic biofilms dwelling on monumental fountains. - Microb. Ecol. 60: 81-95.

El-Sheekh, M.M.; El-Shouny, W.A.; Osman, M.E.H. \& EL-Gammal, E.W.E. (2005): Growth and heavy metals removal efficiency of Nostoc muscorum and Anabaena subcylindrica in sewage and industrial wastewater effluents. - Environ. Toxicol. Pharmacol. 19: 357-365.

de Halperin, D.R.; de Cano, M.S.; de Mule, M.C.Z. \& de CAIRE, G.Z. (1992): Diazotrophic cyanobacteria from argentine paddy fields. - Phyton 53: 135-142.

Hrouzek, P.; ŠImeK, M. \& KomÁreK, J. (2003): Nitrogenase activity and diversity of six soil Nostoc strains. Algological Studies 146: 87-101.

Hrouzer, P.; Ventura, S.; Lukešová, A.; Mugnai, M.A.; Turicchia, S. \& KomÁreK, J. (2005): Diversity of soil Nostoc strains: phylogenetic and phenotypic variability. - Algological Studies 117: 1-14.

Hrouzek, P.; Tomek, P.; LukeŠová, A.; Urban J.; Voloshko, L.; Pushraraj, B.; Ventura, S.; LukavskÝ, J.; ŠTYs, D. \& KopeckÝ, J. (2011): Cytotoxicity and secondary metabolites production in terrestrial Nostoc strains originating from different climatic/ geographic regions and habitats: Is their cytotoxicity rnvironmentally dependent? - Environ. Tox. 26: 345-358.

Johansen, J.R.; St. Clair, L.L.; Webb, B.L. \& Nebeker, G.T. (1984): Recovery patterns of cryptogamic soil crusts in desert rangelands following fire disturbance. The Bryologist 87: 238-243.

Lazaroff, N. \& Vishniac, W. (1961): The effect of light on the developmental cycle of Nostoc muscorum, a filamentous blue-green alga. - J. Gen. Microbiol. 25: $365-374$.

Lazaroff, N. (1966): Photoinduction and photoreversal of the Nostocacean developmental cycle. - J. Phycol. 2: 7-17.

Leghari, M.K.; Qureshi, R.M.; Mashiatullah, A.; Yaqoob, N. \& JAVED, T. (2005): Harmful algal species from various freshwater localities of Pakistan. - Int. J. Phycol. Phycochem. 1: 199-206.

Ludwig, W.; StrunK, O.; Westram, R.; Richter, L.; Meier, H.; Yadhukumar, Buchner, A.; Lai, T.; Steppi, S.; Jobb, G.; Förster, W.; Brettske, I.; Gerber, S.; Ginhart, A.W.; Gross, O.; Grumann, S.; Hermann, S.; Jost, R.; König, A.; Liss, T.; LÜssmann, R.; May, M.; Nonhoff, B.; Reichel, B.; Strehlow, R.; Stamatakis, A.; Stuckmann, N.; Vilbig, A.; Lenke, M.; Ludwig, T.; Bode, A. \& Schleifer, K.H. (2004): ARB: a software environment for sequence data. Nucleic Acids Res. 32: 1363-1371.

LUKEŠOvÁ, A., (1993): Soil algae in four secondary successional stages on abandoned fields. Algological Studies 71: 81-102.

LuKEŠOVÁ, A. \& TAJOVSKÝ, K. (1999): Interactions between soil algae and saprophagous invertebrates (Diplopoda and Oniscidea). - In: TAJovskŕ, K. \& PIŽL, V. (eds): Soil Zoology in Central Europe. - pp. 187-195, Institute of Soil Biology AS CR, České Budějovice.

LuKEŠOVÁ, A. (2001): Soil algae in brown coal and lignite post-mining areas in central Europe (Czech Republic and Germany). - Rest. Ecol. 9: 341-350.

Lukešová, A.; Johansen, J.R.; Martin, M.P. \& Casamatta, D.A. (2009): Aulosira bohemensis sp. nov.: further phylogenetic uncertainty at the base of the Nostocales (Cyanobacteria). - Phycologia 48: 118-129.

Mateo, P.; Perona, E.; Berrendero, E.; Leganes, F.; Martin, M. \& Golubic, S. (2011): Life cycle as a stable trait in the evaluation of diversity of Nostoc from biofilms in rivers. - FEMS Microbiol. Ecol. 76: 185 - 198.

Mollenhauer, D. (1970): Beiträge zur Kenntnis der Gattung Nostoc, I. - Abh. Senckenb. Naturf. Ges. 524: $1-80$.

NovichKova-Ivanova, L.N. (1980): Soil algae of the Sahara-Gobi Desert region. Pochvennyje vodosli fitocenozov saharo-gobijskoj pustynnoj oblasti. 255 pp., Nauka, Leningrad. (In Russian).

O’Brien, H.E.; Miadlikowska, J. \& Lutzoni, F. (2006): Assessing host specialization in symbiotic cyanobacteria associated with four closely related species of the lichen fungus Peltigera. - Eur. J. Phyc. 40: $363-378$.

Papaefthimiou, D.; Hrouzek, P.; Mugnai, M.A.; Rasmussen, U.; LukešovÁ, A.; Turicchia, S. \& Ventura, S. (2008): Differential patterns of evolution and distribution of the symbiotic behaviour in nostocacean cyanobacteria. - Int. J. Syst. Evol. Microbiol. 58: 553-564.

Pruesse, E.; Peplies, J. \& Glöckner, F.O. (2012): SinA: accurate high-throughput multiple sequence 
alignment of ribosomal RNA genes. - Bioinformatics 28: $1823-1829$.

Quast, C.; Pruesse, E.; Yilmaz, P.; Gerken, J.; Schweer, T.; Yarza, P.; Peplies, J. \& Glöckner, F.O. (2013): The SILVA ribosomal RNA gene database project: improved data processing and web-based tools. Nucleic Acids Res. 41: 590-596.

Rajaniemi, P.; Hrouzek, P.; KaštovskÁ, K.; Willame, R.; Rantala, A.; Hoffmann, L.; Komárek, J. \& Sivonen K. (2005): Phylogenetic and morphological evaluation of the genera Anabaena, Aphanizomenon, Trichormus and Nostoc (Nostocales, Cyanobacteria). - Int. J. Syst. Evol. Microbiol. 55: 11-26.

Řeháková, K.; Johansen, J.R.; Casamatta, D.A.; Xuesong, L. \& VINCENT, J. (2007): Morphological and molecular characterization of selected desert soil cyanobacteria: three species new to science including Mojavia pulchra gen. et sp. nov. - Phycologia 46: 481-502.

Rippka, R.; Deruelles, J.; Waterbury, J.; Herdman , M. \& Stanier, R. (1979): Generic assignments, strain histories and properties of pure cultures of cyanobacteria. - J. Gen. Microbiol. 111: 1-61.

Rogers, S.L. \& Burns, R.G. (1994): Change in aggregate stability, nutrient status, indigenous microbialpoplutations, and seedlings emegrence, following inoculation of soil with Nostoc muscorum. - Biol. Fert. Soil. 18: 209-215

Sili, C.; Mascalchi, C. \& Ventura, S. (2011): Evolutionary differentiation of the sister cyanobacterial genera Cyanospira Florenzano, Sili, Pelosi et Vincenzini and Anabaenopsis (Woloszynska) Miller in response to extreme life conditions. - Fottea 11: 107-117.
Skuja, H. (1964): Grundzüge der Algenflora und Algenvegetation der Fjeldgegenden um Abisko in Schwedisch Lappland. - Nova Acta Regiae Soc Sci Ups Ser I, 18: 1-465.

Svenning, M. M.; Eriksson, T. \& Rasmussen, U. (2005): Phylogeny of symbiotic cyanobacteria within the genus Nostoc based on 16S rDNA sequence analyses. - Arch. Microbiol. 183: 19-26.

TAMAS, I.; SVIRCEV, Z. \& ANDERSSON, S. G. (2000): Determinative value of a portion of the nifH sequence for the genera Nostoc and Anabaena (cyanobacteria). - Curr. Microbiol. 41: 197-200.

TomeK, P. (2010): Muscotoxins: novel cytotoxic undecapeptides with unique structural elements and mechanisms of action, isolated from soil cyanobacterium Nostoc muscorum [Ms Thesis]. 89 pp., Faculty of Science, The University of South Bohemia, České Budějovice, Czech Republic.

Uzunov, B.A.; Stoyneva, M.P. \& GÄrtner, G. (2008): Review of the studies on aero-terrestrial cyanoprokaryotes and algae in Bulgaria with a Checklist of the recorded species. II. - Phytologia balcanica 14: 11-18.

(C) Czech Phycological Society (2013)

Received March 10, 2013

Accepted May 15, 2013 